\title{
PERSEPSI SISWA TENTANG KONDISI SOSIAL EKONOMI ORANG TUA DAN INTENSITAS BIMBINGAN BELAJAR TERHADAP PRESTASI BELAJAR SISWA
}

\author{
Mahbub Afandi \\ SMK Islam Trenggalek \\ afandimahbub@yahoo.com
}

\begin{abstract}
This research aims to examine the effect of student's perception about social economic of their parents and learning intensity towards student's achievement. Population of this research are 80 student at XI IPS. Data collection is done by using questionarre and documentation. Data analysis uses regression. The result shows that student's perception about sosial economic of their parents and learning intensity has significant effect on student achievement.
\end{abstract}

Keywords: Sosial economic of parents, Learning intensity, student achievement

Abstrak: Penelitian ini bertujuan untuk menguji pengaruh persepsi siswa tentang kondisi sosial ekonomi orang tua dan intensitas bimbingan belajar siswa terhadap prestasi belajar siswa. Populasi penelitian sebanyak 80 siswa kelas XI IPS. Data dikumpulkan dengan angket dan dokumentasi. Analisis data menggunakan regresi. Hasil penelitian menunjukkan bahwa persepsi siswa tentang kondisi sosial ekonomi orang tua dan intensitas bimbingan belajar siswa berpengaruh secara signifikan terhadap prestasi belajar siswa.

Kata kunci: Kondisi sosial ekonomi orang tua, intensitas bimbingan belajar, prestasi belajar

Pendidikan merupakan proses pendewasaan diri seseorang. Melalui pendidikan akan tercipta perubahan tingkah laku dari seseorang yaitu dari yang sebelumnya tidak tahu menjadi tahu dan mengerti tentang sesuatu hal. Menurut Undang-Undang No.20 tahun 2003 tentang Sistem Pendidikan Nasional bahwa pendidikan merupakan usaha sadar dan terencana untuk mewujudkan suasana belajar dan proses pembelajaran agar peserta didik secara aktif mengembangkan potensi dirinya untuk memiliki kekuatan spiritual, keagamaan, pengendalian diri, kepribadian, kecerdasan, akhlak mulia, serta ketrampilan yang diperlukan dirinya, masyarakat, bangsa dan negara. Berdasarkan pengertian di 
atas, maka pendidikan formal sangat penting bagi setiap orang dapat mengembangkan potensi dirinya dan kelak akan berguna bagi dirinya sendiri, masyarakat, bangsa, dan negara.

Untuk memenuhi kebutuhan akan pendidikan tersebut, manusia memasuki dunia pendidikan formal melalui proses belajar dan dalam proses belajar tersebut muncul pengaruh yang dapat membawa perubahan sikap atas diri seseorang kearah lebih maju. Dalam melaksanakan proses pembelajaran (pendidikan), maka dibutuhkan partisipasi dari berbagai pihak karena keberhasilan dari proses pendidikan tidak hanya bergantung pada pendidik maupun peserta didik itu sendiri, tetapi juga dipengaruhi oleh faktor luar, yaitu lingkungan sekolah, keluarga, dan masyarakat. Dalam pendidikan formal, fenomena belajar mengajar yang dapat dilihat sebagai suatu proses belajar mengajar lebih menekankan pada terciptanya kegiatan pada diri siswa. Pada masyarakat modern tugas dan tanggung jawab pendidikan pada anak diserahkan kepada suatu lembaga yaitu sekolah. Sekolah merupakan tempat melakukan kegiatan belajar mengajar dalam usaha untuk meningkatkan kualitas sumber daya manusia. Slamento (2003:2) mendefinisikan belajar sebagai suatu proses usaha yang dilakukan seseorang untuk memperoleh suatu tingkah laku yang baru secara keseluruhan sebagai hasil dari pengalamannya sendiri dalam interaksi dengan lingkungannya.

Sekolah sebagai wadah dalam proses pembelajaran diharapkan mampu berperan dalam mengembangkan potensi dan bakat siswa, melalui berbagai kegiatan pembelajaran. Untuk menunjang potensi kegiatan belajar siswa, maka memerlukan dukungan sarana dan prasarana sekolah yang memadai, sehingga siswa mampu berkembang secara optimal dan dapat meraih prestasi yang membanggakan.

Faktor kondisi ekonomi banyak ikut berperan menentukan perkembangan dan pendidikan anak disamping sebagai faktor penting bagi kesejahteraan keluarga. Hamalik (2004:182) menyatakan bahwa tingkat pendidikan orang tua, tingkat ekonomi, sikap keluarga terhadap masalah-masalah sosial, realita kehidupan, dan lain-lain merupakan faktor yang akan memberikan pengalaman kepada anak-anak dan menimbulkan perbedaan dalam minat, apresiasi, sikap dan pemahaman ekonomis, perbendaharaan bahasa, abilitas berkomunikasi dengan orang lain, modus berfikir, kebiasaan berbicara, dan pola hubungan kerjasama dengan orang lain. Perbedaan-perbedaan ini akan sangat berpengaruh terhadap tingkah laku dan kegiatan belajar siswa di sekolah. 
Gunarso dalam Handayani (1994:147) menyatakan bahwa status sosial ekonomi menentukan posisi seseorang atau kelompok ditengah-tengah individu atau kelompok lain dalam suatu masyarakat. Kriteria tinggi rendahnya status sosial dalam masyarakat adalah kepemilikan sejumlah barang-barang mewah yang dimiliki seseorang. Status sosial ekonomi orang tua mempunyai pengaruh yang kuat dalam menciptakan suasana belajar siswa. Orang tua yang tingkat sosial ekonominya tinggi belum tentu loyal dalam pemenuhan fasilitas sarana dan prasarana belajar siswa, sebaliknya ada orang tua yang latar belakang sosialnya rendah tetapi perhatiannya sangat besar terhadap pemenuhan sarana dan prasarana belajar siswa. Dalam kehidupan sehari-hari sering dijumpai siswa dengan kondisi ekonomi orang tua yang pas-pasan mempunyai semangat belajar yang kuat sehingga menghasilkan prestasi yang memuaskan. Namun ada kalanya dijumpai keadaan yang sebaliknya, kondisi ekonomi orang tua siswa yang tinggi prestasi belajar anaknya rendah karena mereka tidak mempunyai semangat belajar yang tinggi. Dengan demikina dihipotesiskan sebagai berikut:

$\mathrm{H}_{1}$ : Persepsi siswa tentang kondisi sosial ekonomi orang tua berpengaruh terhadap prestasi belajar siswa

Faktor lain yang diduga berkontribusi terhadap prestasi belajar siswa adalah intensitas bimbingan belajar siswa. Untuk bisa berkembang siswa juga harus diberikan arahan dan bimbingan dalam belajar agar terdorong untuk menyesuaikan diri dengan lingkungan dan bisa belajar dengan baik, serta menentukan alternatif-alternatif dalam memecahkan kesulitan belajar. Menurut Partowisastro (1985:12), bimbingan adalah bantuan yang diberikan kepada seseorang agar mengembangkan potensi-potensi yang dimiliki mengenai dirinya sendiri, mengatasi persoalan-persoalan sehingga dapat menentukan sendiri jalan hidupnya serta bertanggung jawab tanpa bergantung dengan orang lain.

Pendidikan non formal diselenggarakan bagi warga masyarakat yang memerlukan layanan pendidikan yang berfungsi sebagai pengganti, penambah, dan pelengkap pendidikan formal dalam rangka mendukung pendidikan sepanjang hayat. Satuan pendidikan non formal terdiri atas lembaga kursus, kelompok belajar dan pusat kegiatan belajar masyarakat (Undang-Undang Sistem Pendidikan Nasional No.20 tahun 2003, pasal 26 ayat 1). Dengan adanya bimbingan belajar di luar sekolah yang menjadi intensitas bimbingan belajar siswa menjadi lebih banyak sehingga akan dapat 
meningkatkan prestasi belajar anaknya di sekolah. Penelitian yang dilakukan oleh Widianto (2006) untuk mendeskripsikan pengaruh motivasi dan bimbingan belajar oleh orang tua terhadap prestasi belajar yang menggunakan pendekatan deskriptif kuantitatif menunjukan terdapat hubungan yang signifikan antara pengaruh motivasi dan bimbingan belajar oleh orang tua terhadap prestasi belajar siswa. Dengan demikian dihipotesiskan sebagai berikut:

$\mathrm{H}_{2}$ : Intensitas belajar siswa berpengaruh terhadap prestasi belajar siswa

Penelitian ini dilaksanakan di SMA Negeri I Durenan. Lokasi tersebut dipilih dengan pertimbangan bahwa SMA Negeri I Durenan input yang diperoleh dari siswasiswanya relatif sangat rendah tetapi out put yang dihasilkan tinggi. Berdasarkan hasil survei sementara tahun 2007/2008 NEM SMP 25,41 dengan tingkat kelulusan rata-rata 47,70 (Staf Tata Usaha SMA Negeri 1 Durenan). Selain itu SMA Negeri 1 Durenan ini telah memperoleh predikat sebagai sekolah yang berstandar nasional sehingga ingin diketahui seberapa jauh peranan sosial ekonomi orang tua dan intensitas bimbingan belajar turut andil dalam pencapaian prestasi belajar siswanya.

\section{METODE}

Penelitian ini dikategorikan sebagai penelitian eksplanasi. Penelitian eksplanasi adalah suatu penelitian yang menguji hubungan antar variabel atau untuk menguji suatu teori. Penelitian ini bertujuan untuk mengetahui pengaruh antara variabel bebas terhadap variabel terikat. Variabel bebas dalam penelitian ini terdiri dari dua yaitu persepsi tentang kondisi sosial ekonomi orang tua dan intensitas bimbingan belajar, sedangkan variabel terikatnya adalah prestasi belajar siswa. Kondisi sosial ekonomi adalah kondisi atau kedudukan seseorang dalam masyarakat yang dilihat dari pendidikan, pekerjaan, dan status sosial dalam masyarakat. Variabel ini diukur menggunakan skala sikap yang terdiri dari lima skala yang diadopsi dari model Likert's Scale berupa skala penilaian 1 sampai dengan 5, mulai sangat tinggi sampai sangat rendah. Bimbingan Belajar adalah kegiatan sistematis yang diberikan kepada siswa agar dapat memahami diri sendiri dan mengarahkannya untuk mencapai tujuan yang ingin dicapai. Variabel ini diukur dengan menggunakan skala berupa skala sikap menggunakan skala Likert berupa skala penilaian 1 sampai dengan 5, mulai dari selalu sampai tidak pernah. Prestasi belajar adalah suatu kemampuan yang dimiliki oleh siswa 
yang berupa pengetahuan, keterampilan, sikap dan tingkah laku yang diperolehnya dari belajar melalui pengalamannya sendiri maupun dengan berinteraksi dengan lingkungannya. Prestasi belajar dalam penelitian ini diukur menggunakan nilai hasil ujian akhir semester.

Populasi yang penelitian ini adalah semua siswa kelas XI IPS SMA Negeri 1 Durenan semester genap yang berjumlah 80 siswa, dengan rincian sebagai berikut:

\section{Tabel 1. Jumlah Siswa Kelas XI IPS}

\begin{tabular}{|l|l|l|}
\hline \multicolumn{1}{|c|}{ No. } & \multicolumn{1}{|c|}{ Kelas } & \multicolumn{1}{c|}{ Jumlah } \\
\hline 1. & XI IPS 1 & 40 \\
2. & XI IPS 2 & 40 \\
& Jumlah & 80 \\
\hline
\end{tabular}

Sumber : (Staf Tata Usaha)

Oleh karena jumlah populasi kurang dari 100, maka diambil semua sehingga penelitian ini merupakan penelitian populasi. Data yang digunakan dalam penelitian ini adalah data primer dan data sekunder. Data primer dikumpulkan melalui angket sedangkan data sekunder dikumpulkan melalui dokumentasi. Penelitian ini menggunakan analisis regresi ganda untuk mengetahui pengaruh keseluruhan variabel bebas terhadap variabel terikat.

Hubungan antara variabel tersebut dapat digambarkan sebagai berikut:

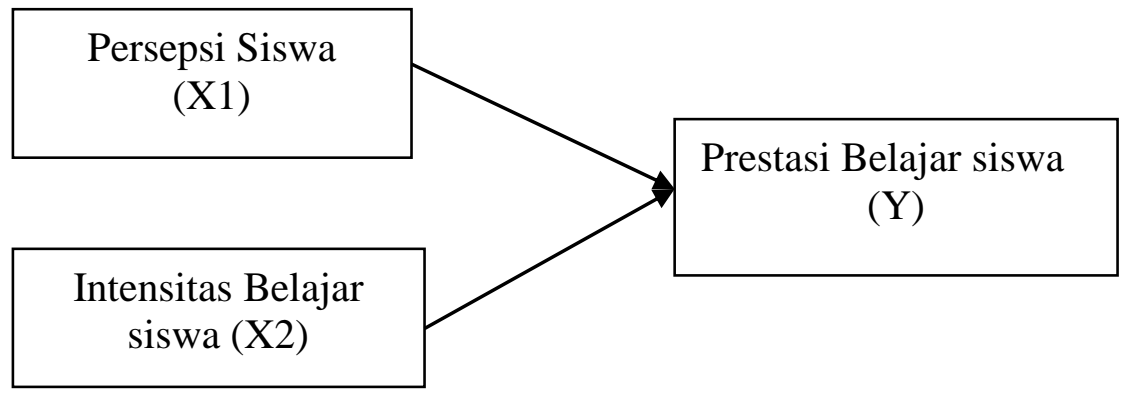

\section{Gambar 3.1 Model Penelitian}

Persamaan dari model diatas adalah sebagai berikut:

$$
y_{i}=a+\beta_{1} X_{i 1}+\beta_{2} X_{i 2}+e_{i}
$$

Keterangan :

$\mathrm{X}_{1} \quad$ : Kondisi sosial ekonomi orang tua

$\mathrm{X}_{2}$ : Intensitas bimbingan belajar

Y : Prestasi belajar siswa 
Penelitian ini telah melalui uji validitas dan uji reliabilitas. Uji validitas adalah suatu ukuran yang menunjukkan tingkat-tingkat kesulitan atau kesahihan suatu instrumen. Instrumen yang valid atau sahih mempunyai validitas cukup tinggi, sebaliknya instrumen yang kurang valid mempunyai validitas yang rendah (Arikunto, 2002:146). Sebuah instrumen dikatakan valid apabila mampu mengukur apa yang diinginkan. Sebuah instrumen dikatakan valid apabila mengungkap data dari variabel yang diteliti secara tepat.

Berikut ini merupakan hasil uji validitas instrumen kondisi sosial ekonomi orang tua kelas XI IPS SMA Negeri I Durenan.

Tabel 2. Ringkasan Hasil Uji Validitas Instrumen

\begin{tabular}{|l|l|l|l|}
\hline Item & $\mathbf{r}$ hitung & $\mathbf{r}$ table & Kesimpulan \\
\hline 1 & 0,796344723 & 0,497 & Valid \\
\hline 2 & 0,753289381 & 0,497 & Valid \\
\hline 3 & 0,864452309 & 0,497 & Valid \\
\hline 4 & 0,676584559 & 0,497 & Valid \\
\hline 5 & 0,559681786 & 0,497 & Valid \\
\hline 6 & 0,563757715 & 0,497 & Valid \\
\hline 7 & 0,594983142 & 0,497 & Valid \\
\hline 8 & 0,603732658 & 0,497 & Valid \\
\hline 9 & 0,564228797 & 0,497 & Valid \\
\hline 10 & 0,745548831 & 0,497 & Valid \\
\hline 11 & 0,821215591 & 0,497 & Valid \\
\hline 12 & 0,837412212 & 0,497 & Valid \\
\hline 13 & 0,552474792 & 0,497 & Valid \\
\hline 14 & 0,675400068 & 0,497 & Valid \\
\hline 15 & 0,811769629 & 0,497 & Valid \\
\hline 16 & 0,562887829 & 0,497 & Valid \\
\hline
\end{tabular}

Sumber: Hasil Uji Validitas

Dari tabel di atas dapat dilihat bahwa analisis perhitungan Pearson Correlation dengan $\mathrm{N}$ of item 16 pada taraf signifikansi 0,05 memperoleh hasil bahwa 16 butir soal mempunyai nilai $r>0,3$ dengan demikian butir soal dikatakan mempunyai validitas tinggi. 
Berikut ini merupakan hasil uji validitas instrumen intensitas bimbingan belajar kelas XI IPS SMA Negeri I Durenan

Tabel 3. Ringkasan Hasil Uji Validitas Instrumen

\begin{tabular}{|l|l|l|l|}
\hline Item & $\mathrm{r}_{\text {hitung }}$ & $\mathrm{r}_{\text {table }}$ & Kesimpulan \\
\hline 1 & 0.621462723 & 0,576 & Valid \\
\hline 2 & 0.613367801 & 0,576 & Valid \\
\hline 3 & 0.605421614 & 0,576 & Valid \\
\hline 4 & 0.615123562 & 0,576 & Valid \\
\hline 5 & 0.694785266 & 0,576 & Valid \\
\hline 6 & 0.622407668 & 0,576 & Valid \\
\hline 7 & 0.623144325 & 0,576 & Valid \\
\hline 8 & 0.593746223 & 0,576 & Valid \\
\hline 9 & 0.602078214 & 0,576 & Valid \\
\hline 10 & 0.594575025 & 0,576 & Valid \\
\hline 11 & 0.608903394 & 0,576 & Valid \\
\hline 12 & 0.604453098 & 0,576 & Valid \\
\hline
\end{tabular}

Sumber: Hasil Uji Validitas

Dari tabel di atas dapat dilihat bahwa analisis perhitungan Pearson Correlation dengan $\mathrm{N}$ of item 12 pada taraf signifikansi 0,05 memperoleh hasil bahwa 12 butir soal mempunyai $r>0,3$, dengan demikian butir soal dikatakan mempunyai validitas tinggi.

Reliabilitas menunjuk pada satu pengertian bahwa suatu instrumen cukup dapat dipercaya untuk digunakan sebagai alat pengumpul data karena instrumen tersebut sudah baik (Arikunto,2002:154). Berikut ini merupakan uji reliabilitas instrumen penelitian.

\section{Tabel 4. Hasil Uji Reliabilitas Instrumen}

\begin{tabular}{|l|l|l|l|l|}
\hline No. & \multicolumn{1}{|c|}{ Variabel } & $\begin{array}{c}\text { Cronbach } \\
\text { alpha }\end{array}$ & \multicolumn{1}{|c|}{$\begin{array}{c}\text { Jumlah item } \\
\text { soal }\end{array}$} & Keterangan \\
\hline 1. & $\begin{array}{l}\text { Kondisi Sosial Ekonomi } \\
\text { Orang Tua (X1) }\end{array}$ & 0,927 & 16 & $\begin{array}{l}\text { Sangat } \\
\text { Reliabel }\end{array}$ \\
\hline 2. & $\begin{array}{l}\text { Intensitas Bimbingan } \\
\text { Belajar (X2) }\end{array}$ & 0,847 & 12 & $\begin{array}{l}\text { Sangat } \\
\text { Reliabel }\end{array}$ \\
\hline
\end{tabular}

Sumber: Hasil Uji Realibitas

Dari hasil uji reliabilitas yang dilakukan terhadap instrumen berupa angket yang digunakan peneliti, diketahui bahwa tingkat reliabilitas instrumen variabel kondisi sosial ekonomi orang tua mencapai 0.927 dan instrumen intensitas bimbingan belajar sebesar 0.847. Sehingga instrumen variabel kondisi sosial ekonomi orang tua dan instrumen intensitas bimbingan belajar dapat dikatakan reliabel dengan kategori sangat tinggi. 


\section{HASIL DAN PEMBAHAAN}

\section{Hasil}

Analisis regresi ganda digunakan untuk mengetahui pengaruh keseluruhan variabel bebas terhadap variabel terikat. Secara ringkas hasil uji regresi ganda dapat dilihat pada tabel 5 .

\section{Tabel 5. Ringkasan Hasil Uji Regresi Ganda}

\begin{tabular}{|c|c|c|c|c|}
\hline Variabel & & $\beta$ & $\mathrm{t}_{\text {hitung }}$ & Sig-t \\
\hline Kondisi sosial ekono & $\mathrm{i}(\mathrm{X} 1)$ & 0.548 & 6.071 & 0.000 \\
\hline Intensitas bimbingan & elajar (X2) & 0.221 & 2.453 & 0.016 \\
\hline Konstanta & $: 56.711$ & & & \\
\hline Multiple R & $: 0.632$ & & & \\
\hline $\mathrm{R}$ square & $: 0.399$ & & & \\
\hline Adjusted R Square & $: 0.384$ & & & \\
\hline $\mathrm{F}_{\text {hitung }}$ & 25.584 & & & \\
\hline$F_{\text {tabel }}$ & $: 2.69$ & & & \\
\hline $\operatorname{Sig} F$ & : 0.000 & & & \\
\hline
\end{tabular}

Sumber : Hasil Pengolahan data dengan SPSS for Windows

Dari hasil analisis data, diketahui untuk variabel kondisi sosial ekonomi orang tua diperoleh nilai $\beta$ sebesar 0.548 dan probabilitas 0.000 sehingga dapat disimpulkan bahwa secara parsial variabel kondisi sosial ekonomi orang tua mempunyai pengaruh positif terhadap prestasi belajar siswa sedangkan untuk variabel intensitas bimbingan belajar diperoleh nilai $\beta$ sebesar 0.221 dan probabilitas 0.016 sehingga dapat disimpulkan bahwa secara parsial variabel intensitas bimbingan belajar mempunyai pengaruh positif terhadap prestasi belajar siswa.

\section{Pembahasan}

\section{Pengaruh Kondisi Sosial Ekonomi Orang Tua Terhadap Prestasi Belajar Siswa}

Hasil penelitian menunjukkan bahwa persepsi siswa tentang kondisi sosial ekonomi orang tua berpengaruh terhadap prestasi belajar siswa. Kondisi sosial ekonomi orang tua banyak menentukan perkembangan dan pendidikan siswa disamping sebagai faktor penting bagi kesejahteraan keluarga misalnya keluarga yang ekonominya tinggi, menyebabkan lingkungan materiil yang dihadapi oleh siswa di dalam keluarganya lebih luas, sehingga mempunyai kesempatan yang lebih besar untuk memperoleh sarana dan fasilitas belajar yang menunjang pendidikan siswa. Berbeda dengan keluarga yang kondisi sosial ekonomi orang tua rendah, biasanya akan menyebabkan terhambatnya 
perkembangan belajar siswa, tapi semua itu tergantung karakteristik siswa dan komunikasi dengan keluarga. Siswa yang mandiri dan pantang menyerah dengan kondisi sosial ekonomi orang tua yang kurang baik juga cenderung semangat untuk mencapai prestasi yang lebih baik dalam dunia pendidikan.

Mifflen (1992:22) mengemukakan bahwa status sosial ekonomi menunjukkan pada kedudukan seseorang dalam suatu rangkaian strata yang tersusun hirarki yang merupakan kesatuan tertimbang dari hal-hal yang mempunyai nilai dalam suatu masyarakat yang biasa dikenal sebagai privilese (kekayaan, pendapatan, barang-barang konsumsi), prestise (status gaya hidup) dan kekuasaan. Hasil penelitian ini mendukung penelitian sebelumnya yang dilakukan oleh Novitasari (2007) yang menyatakan bahwa kondisi sosial ekonomi mempengaruhi prestasi siswa pada mata pelajaran ekonomi di SMA Negeri 1 Kauman TulungAgung. Dengan demikian, dapat disimpulkan bahwa kondisi sosial ekonomi orang tua yang tinggi akan membantu siswa dalam proses belajar sehingga siswa lebih termotivasi untuk belajar dengan optimal kemudian secara berkelanjutan dapat mempengaruhi siswa tersebut dalam mencapai prestasi belajar yang lebih baik.

\section{Pengaruh Intensitas Bimbingan Belajar Terhadap Prestasi Belajar Siswa}

Hasil penelitian menunjukkan bahwa intensitas bimbingan belajar berpengaruh secara signifikan terhadap prestasi belajar siswa. Bimbingan belajar sebagai proses pemberian bantuan terhadap individu untuk dapat memahami diri sendiri, dan mengarahkannya untuk mencapai tujuan yang ingin dicapai individu tersebut mengenai kegiatan belajarnya. Bimbingan biasanya dapat dilakukan di dalam sekolah dan di luar sekolah. Banyak kegiatan siswa diluar sekolah yang bisa dilakukan, biasanya orang tua yang mempunyai perhatian kepada anaknya, akan senantiasa memberikan dorongan dan bimbingan agar anaknya tersebut mau belajar. Menurut Partowisastro (1985:12), bimbingan adalah bantuan yang diberikan kepada seseorang agar mengembangkan potensi-potensi yang dimiliki mengenai dirinya sendiri, mengatasi persoalan-persoalan sehingga dapat menentukan sendiri jalan hidupnya serta bertanggung jawab tanpa bergantung dengan orang lain.

Hasil penelitian ini sesuai dengan penelitian yang dilakukan oleh Widianto (2006) yang menyatakan bahwa terdapat hubungan yang signifikan antara pengaruh motivasi dan bimbingan belajar oleh orang tua terhadap prestasi belajar siswa. 
Keluarga yang mempunyai waktu luang dapat lebih memperhatikan kagiatan belajar anak, sehingga dengan bimbingan dari orang tua secara langsung prestasi belajar anak dapat dipantau dan peran orang tua dalam melakukan pengarahan dan bimbingan menjadi maksimal. Hal ini akan mempengaruhi prestasi belajar anak di sekolah. Berbeda dengan keluarga yang mempunyai aktivitas atau kesibukan yang cukup padat biasanya mempunyai alternatif untuk dapat memberikan dukungan bagi kegiatan anak, sekarang banyak jasa-jasa bimbingan privat dan bimbingan melalui lembaga bimbingan belajar tertentu.

\section{PENUTUP}

\section{Simpulan dan saran}

Bardasarkan hasil penelitian, persepsi siswa tentang kondisi sosial ekonomi orang tua dan intensitas belajar siswa mempunyai pengaruh positif terhadap prestasi belajar siswa pada bidang studi akuntansi kelas XI IPS di SMA Negeri 1 Durenan. Hal ini mengindikasikan bahwa semakin baik kondisi sosial ekonomi dalam sebuah keluarga semakin baik pula prestasi belajar siswa karena orang tua akan memfasilitasi siswa untuk belajar dengan baik. Selain itu, semakin tinggi intensitas bimbingan belajar siswa juga akan berdampak pada tingginya prestasi yang dicapai oleh seorang siswa. Penelitian ini hanya dilakukan pada sampel yang terbatas yaitu kelas XI IPS sehingga untuk penelitian berikutnya diharapkan memperluas sampel. Selain itu, peneliti berikutnya diharapkan dapat menambahkan variabel-variabel lain yang diduga sebagai determinan prestasi belajar siswa.

\section{DAFTAR PUSTAKA}

Arikunto, Suharsimi. 2002. Prosedur Penelitian Pendekatan Suatu Praktek. Jakarta: Rineka Cipta.

Undang-Undang Republik Indonesia No. 20 Tahun 2003 Tentang Sistem Pendidikan Nasional. Bandung: Citra Umbara.

Arikunto, Suharsimi. 2003. Dasar-DasarEvaluasi Pendidikan. Jakarta: Bumi Aksara. 
Gunarsa, Singgih. 1990. Psikologi Untuk Membimbing. Jakarta Pusat: PT. Bpk Gunung Mulya.

Hamalik, Oemar. 2000. Metode Belajar dan Kesulitan Belajar. Bandung: Tarsito.

Slameto. 2003. Belajar dan Faktor-faktor yang Mempengaruhi. Jakarta: Cipta Aksara.

Hakim, T. 2000. Belajar Secara Efektif, Panduan Menemukan Teknik Belajar, Memilih Jurusan dan Menentukan Cita-Cita. Jakarta: Pustaka Pembangunan Swadaya Nusantara.

Dimyati dan Mudjiono. 2002. Belajar dan Pembelajaran. Jakarta: Pusat Pembukuan Departemen Pendidikan dan Kebudayaan dan PT Rineka Cipta.

Pusat Bahasa Departemen Pendidikan Nasional. 2001. Kamus Besar Bahasa Indonesia. Jakarta: Balai Pustaka.

Tim Jurusan Akuntansi. 2004. Pedoman Penulisan Skripsi Jurusan Akuntansi(PPSJA) sebagai Operasionalisasi dari PPKI UM. Malang: Jurusan Akuntansi UM.

Universitas Negeri Malang. 2003. Pedoman Penulisan Karya Ilmiah. Malang: Universitas Negeri Malang. 